\title{
HUBUNGAN ANTARA FAKTOR EKSTERNAL DENGAN PERILAKU TIDAK AMAN DALAM PENGOPERASIAN OVERHEAD CRANE
}

\section{THE CORRELATION BETWEEN EXTERNAL FACTOR AND UNSAFE BEHAVIOR IN OVERHEAD CRANE OPERATION}

\author{
Fildza Fadhila \\ Ikatan Ahli Kesehatan Masyarakat Indonesia \\ Provinsi Jawa Timur \\ E-mail: fadhfildza@gmail.com
}

\begin{abstract}
Unsafe behavior is a major cause of workplace accidents. Environmental or external factor is dominant factor that can influence a behavior. The present research was conducted at PT. Bangun Sarana Baja (BSB) Gresik which is one of steel industry in construction sector. The purpose of this study was to analyze the corellation between external factor and unsafe behavior of workers in overhead crane operation at PT. Bangun Sarana Baja Gresik. This research was an observational analytic and used cross-sectional design. Population in this research was all of workshop worker that operates overhead crane (OHC) at PT. Bangun Sarana Baja (BSB) Gresik. The samples were 80 people, taken randomly by simple random sampling method. Data which had obtained then was analyzed statistically using correlation of contingency. The results showed that between variables of external factor more of them has a correlation with unsafe behavior in overhead crane operation. They are supervision $(p=0.004)$ and training $(p=0.000)$. The result of this study can be concluded that rather good supervision and unparticipated training by workers can influence their unsafe behavior. So if the value of the both variables improved to be better then it will be able to decrease the unsafe behavior in overhead crane operation.
\end{abstract}

Keywords: external factor, overhead crane, unsafe behavior

\begin{abstract}
ABSTRAK
Perilaku tidak aman (unsafe behaviour) merupakan penyebab utama dari terjadinya kecelakaan kerja. Faktor lingkungan atau faktor eksternal merupakan faktor dominan yang dapat mempengaruhi perilaku seseorang. Penelitian ini dilakukan di PT. Bangun Sarana Baja (BSB) Gresik yang merupakan salah satu industri baja yang bergerak dalam bidang konstruksi. Tujuan dari penelitian ini adalah untuk menganalisis hubungan antara faktor eksternal pekerja dengan perilaku tidak aman pekerja dalam mengoperasikan overhead crane di PT. Bangun Sarana Baja Gresik. Penelitian ini bersifat observasional analitik dengan desain penelitian cross-sectional. Populasi dalam penelitian ini adalah seluruh pekerja workshop yang mengoperasikan overhead crane (OHC) di PT. Bangun Sarana Baja Gresik dengan total jumlah 99 orang. Besar sampel penelitian adalah 80 orang, diambil secara acak dengan menggunakan metode simple random sampling. Data yang diperoleh kemudian dianalisis secara statistik dengan menggunakan uji korelasi kontingensi. Hasil penelitian menunjukkan bahwa variabel faktor eksternal mendominasi dengan memiliki hubungan antara perilaku tidak aman pekerja dalam pengoperasian overhead crane. Variabel faktor eksternal yang berhubungan dengan perilaku tidak aman adalah pengawasan $(\mathrm{p}=0,004)$ dan pelatihan $(\mathrm{p}=0,000)$. Hasil dari penelitian dapat disimpulkan bahwa pengawasan yang cukup baik dan ketidakikutsertaan pekerja dalam pelatihan dapat mempengaruhi perilaku tidak aman pekerja, sehingga apabila nilai kedua variabel tersebut ditingkatkan menjadi lebih baik maka akan dapat menurunkan perilaku tidak aman pekerja dalam pengoperasian overhead crane.
\end{abstract}

Kata kunci: faktor eksternal, overhead crane, perilaku tidak aman

\section{PENDAHULUAN}

Industri baja, khususnya dalam bidang konstruksi, merupakan salah satu industri yang menjadi pilar penting dalam pembangunan infrastruktur. Masa depan pembangunan Indonesia salah satunya ditentukan oleh perkembangan industri baja. Suatu negara dengan tingkat pengembangan industri baja yang sangat maju dapat dikatakan sebagai negara yang maju dalam bidang industrinya. Hal ini disebabkan prasarana berbahan baku baja banyak dimanfaatkan oleh berbagai produk industri, seperti peralatan mesin, alat angkut, dan konstruksi (Kementerian Perindustrian, 2012). 
Industri baja memiliki berbagai proses dalam produksinya. Salah satunya adalah fabrikasi baja. Fabrikasi merupakan tahap baja disusun lalu disatukan sehingga memenuhi rancangan yang sebelumnya telah dibuat. Proses ini dilakukan oleh tenaga manusia dengan menggunakan peralatan kerja, baik itu peralatan tangan ataupun peralatan berat.

Overhead crane (OHC) merupakan salah satu peralatan berat jenis kran yang kerap digunakan dalam bidang sektor konstruksi berupa jembatan melintang di atas kepala yang terbuat dari rangka batang berlapis plat baja. Mekanisme ini kemudian dapat menghasilkan beberapa gerakan antara lain seperti pengangkatan benda (hoisting system) dan jalan melintang pada jembatan (Bikatofani, 2015). Overhead crane (OHC) dimanfaatkan untuk memindahkan material berat yang tidak bisa dipindahkan dengan menggunakan tenaga manusia secara langsung.

Setiap proses kerja tidak lepas dengan kejadian kecelakaan kerja. Termasuk dalam proses pemakaian overhead crane yang juga memiliki bahaya potensial di dalamnya. Kecelakaan kerja sendiri dapat disebabkan oleh tiga faktor, yaitu faktor manusia, peralatan, dan lingkungan kerja. Berbagai hasil penelitian menunjukkan bahwa faktor yang mendominasi menjadi penyebab kecelakaan kerja adalah faktor manusia. Hal ini seringkali disebabkan oleh kurangnya kesadaran pekerja mengenai seberapa penting keselamatan kerja sehingga mereka tidak menyadari bahaya potensial yang mungkin terjadi (Basuki, 2012).

Data dari Bureau of Labor Statistics (BLS) pada tahun 2006 menunjukkan bahwa terdapat 72 kecelakaan kerja akibat crane. Jenis kecelakaan yang terjadi adalah akibat dari terjatuhnya objek benda yang diangkut dan melukai pekerja hingga pekerja yang terluka akibat benturan crane. Jenis crane yang sering menyebabkan terjadinya kecelakaan kerja yaitu mobile crane, truck and rail mounted crane, dan overhead crane. 26 kejadian kecelakaan crane adalah akibat dari mobile, truck atau rail mounted crane. 19 kejadian merupakan akibat dari overhead crane.

The Center for Construction Research and Training menyebutkan bahwa dari total kematian pekerja konstruksi yang sejumlah 323.307 kejadian merupakan insiden crane dari tahun 1993 hingga 2006. Rata-rata terdapat 22 kematian pekerja konstruksi pada setiap tahunnya. Kejadian kecelakaan kerja pada crane terjadi pada empat jenis utama crane, dari 307 kejadian tersebut, 216 (71\%) kejadian adalah insiden mobile crane, 16 (5\%) merupakan insiden tower crane, 13 (4\%) merupakan floating crane, dan 12 (4\%) adalah overhead crane. Data lain menunjukkan bahwa pada tahun 2008 terdapat 58 kematian akibat dari kecelakaan kerja akibat crane. Selain itu, juga terdapat 126 kejadian pekerja yang mengalami cidera akibat kecelakaan kerja crane, dimana terjadi pada pekerja konstruksi, operator crane, dan pekerja yang mendirikan crane. Pada kecelakaan kerja akibat crane, 71\% kejadian merupakan akibat dari mobile crane, 5\% dari tower crane, dan 24\% merupakan gabungan dari overhead, barge, dan floating crane (The Center for Construction Research and Training, 2010).

Cooper (2009) berpendapat bahwa perilaku manusia merupakan unsur yang memiliki peran penting dalam menyebabkan kecelakaan kerja. Perilaku manusia berupa kelalaian seringkali menjadi penyebab terjadinya kecelakaan kerja. Perilaku tersebut disebut dengan perilaku tidak aman (unsafe behavior). Mengurangi perilaku tidak aman dapat dilakukan sebagai salah satu upaya pengurangan pada kecelakaan kerja dapat terjadi.

Pernyataan tersebut didukung oleh data dari Bureau Labor Statistic yang menyatakan bahwa 90\% kecelakaan kerja akibat crane terjadi karena kesalahan manusia atau human error. Bentuk perilaku tidak aman yang seringkali dilakukan adalah perilaku operator crane yang memberikan beban angkut melebihi dari kapasitas crane, perilaku kontak dengan daya listrik saat pengoperasian crane yang dapat mengakibatkan kematian akibat listrik, atau beban angkut yang tidak dikendalikan dengan baik saat dilakukan penaikkan untuk diangkut sehingga beban dapat melukai pekerja. Data menunjukkan bahwa rata-rata terdapat 80 pekerja pesawat angkat dan angkut yang terbunuh akibat kecelakaan kerja pada setiap tahun (BLS, 2006).

PT. Bangun Sarana Baja (BSB) Gresik merupakan salah satu industri baja yang bergerak dalam bidang konstruksi. PT. Bangun Sarana Baja Gresik memiliki 21 gudang, 20 gudang memiliki overhead crane. Setiap gudang masing-masing memiliki 1 hingga 3 buah overhead crane, dengan total jumlah keseluruhan overhead crane di PT. Bangun Sarana Baja Gresik adalah 42 buah.

PT. Bangun Sarana Baja Gresik merupakan perusahaan yang telah menjalankan SMK3, zero accident diharapkan menjadi output selama proses produksi berlangsung. Kenyataannya kecelakaan kerja masih terjadi di PT. Bangun 
Sarana Baja Gresik. Baik itu kecelakaan yang hanya membutuhkan pertolongan pertama hingga dengan kecelakaan kerja fatality yang membutuhkan pertolongan medis atau perawatan dokter. Data kecelakaan kerja di PT. Bangun Sarana Baja Gresik pada tahun 2016 yang salah satunya disebabkan dan berhubungan dengan pengoperasian overhead crane dapat dilihat dalam Tabel 1.

Tabel 1. Distribusi Kecelakaan Kerja di PT. Bangun Sarana Baja Gresik pada Tahun 2016

\begin{tabular}{lc}
\hline \multicolumn{1}{c}{ Jenis Kecelakaan } & Jumlah Kecelakaan Kerja \\
\hline Terjepit & 6 \\
Luka terbuka & 9 \\
Tertimpa material & 2 \\
Tergores & 3 \\
Lecet & 33 \\
\hline Total & 53 \\
\hline
\end{tabular}

Sumber: P3K PT. Bangun Sarana Baja Gresik

Selain kecelakaan ringan yang hanya membutuhkan perawatan pertolongan pertama tersebut, pada tahun 2016 di PT. Bangun Sarana Baja Gresik juga terdapat kecelakaan yang membutuhkan perawatan dokter yang diakibatkan dalam pengoperasian overhead crane. Data kecelakaan yang membutuhkan perawatan dokter dapat dilihat dalam Tabel 2.

Operator overhead crane (OHC) di PT. Bangun Sarana Baja Gresik merupakan salah satu pekerjaan yang di dalamnya masih banyak terdapat perilaku tidak aman. Pengoperasian overhead crane $(\mathrm{OHC}) \mathrm{di}$ PT. Bangun Sarana Baja Gresik dapat dioperasikan oleh siapa saja, termasuk yang tidak berwenang dalam pengoperasian overhead crane $(\mathrm{OHC})$.

Tabel 2. Kecelakaan Kerja yang Membutuhkan Perawatan Dokter di PT. Bangun Sarana Baja Gresik pada Tahun 2016

\begin{tabular}{lc}
\hline \multicolumn{1}{c}{ Jenis Kecelakaan } & Jumlah Kejadian \\
\hline $\begin{array}{l}\text { Memar pada tulang rusuk } \\
\text { bagian bawah }\end{array}$ & 1 \\
$\begin{array}{l}\text { Jari terjepit rantai chain } \\
\text { block }\end{array}$ & 1 \\
\hline Total & 2 \\
\hline
\end{tabular}

Sumber: P3K PT. Bangun Sarana Baja Gresik
Pernyataan di atas menunjukkan bahwa pekerja dengan tidak memiliki sertifikat pengoperasian overhead crane $(\mathrm{OHC})$ atau yang tidak memiliki lisensi K3 dalam mengoperasikan overhead crane (OHC) juga dapat menjadi operator overhead crane (OHC), yang berarti dapat mempertinggi risiko terjadinya kecelakaan kerja dengan pekerja yang tidak mengikuti pelatihan terlebih dahulu dalam pengoperasian overhead crane (OHC).

Operator overhead crane (OHC) di PT. Bangun Sarana Baja Gresik juga belum melakukan pengoperasian dengan benar dan baik. Seperti pengangkatan beban angkut ke sling overhead crane $(\mathrm{OHC})$ dengan sikap dan langkah yang salah atau pekerja yang tidak menggunakan APD yang sesuai selama pengoperasian overhead crane $(\mathrm{OHC})$ berlangsung.

Oleh karena penggunaan alat berat tersebut berpotensi risiko bahaya, maka diperlukan operator yang handal dan memiliki keterampilan yang memadai di samping itu pula sesuai dengan Perundang-undangan dan Peraturan Menteri Tenaga Kerja No. 5 Tahun 1985 pada pasal 4. Peraturan Menteri Tenaga Kerja RI Per.09/MEN/VII/2010 juga telah menetapkan kualifikasi dan syarat-syarat operator OHC. Setiap operator overhead crane (OHC) harus memiliki sertifikat yang diperoleh melalui pelatihan. Operator pemegang sertifikat memiliki peranan penting dalam mencegah kemungkinan terjadinya kecelakaan kerja dalam mengoperasikan $\mathrm{OHC}$, karena operator mengetahui dan memahami prosedur pengoperasian yang aman. Operator yang telah terkualifikasi dengan kepemilikan lisensi K3 atau SIO juga memiliki arti lain bahwa operator memiliki kompeten untuk mengoperasikan overhead crane serta memiliki tanggung jawab dalam pengoperasian yang dilakukan.

Perilaku merupakan bentuk reaksi terhadap rangsangan dari luar yang diberikan kepada seseorang. Namun meskipun demikian, dalam memberikan suatu reaksi tergantung dari faktor lain yang bersangkutan. Faktor lingkungan atau eksternal merupakan faktor yang memiliki peran penting dalam membentuk perilaku seseorang. Faktor lingkungan dominan mewarnai perilaku seseorang (Notoatmodjo, 2003). Oleh sebab itu, tujuan dari penelitian ini adalah menganalisis hubungan antara faktor eksternal pekerja dengan perilaku tidak aman pekerja dalam pengoperasian overhead crane (OHC). 


\section{METODE}

Penelitian ini termasuk penelitian observational karena peneliti tidak memberikan perlakuan pada subjek penelitian. Berdasarkan segi waktu, penelitian ini bersifat cross-sectional karena pengumpulan data, yang meliputi variabel bebas dan variabel terikat, dilakukan dalam satu periode waktu. Penelitian ini juga bersifat analitik kuantitatif, karena penelitian ini mengambil data dengan memberi bobot atau skor dalam butir pertanyaan di dalam kuesioner.

Populasi dalam penelitian ini adalah seluruh pekerja workshop yang mengoperasikan overhead crane (OHC) di PT. Bangun Sarana Baja Gresik dengan total jumlah 99 orang. Pengambilan sampel menggunakan teknik pengambilan simple random sampling, menurut Slovin ditentukan dengan rumus (Riduwan, 2013), yaitu sebagai berikut:

$$
\mathbf{n}=\frac{\grave{N}}{1+N \bar{e}^{2}}
$$

Keterangan:

$$
\begin{aligned}
\mathrm{n} & =\text { besar sampel } \\
\mathrm{N} & =\text { besar populasi } \\
\mathrm{E} & =\text { kesalahan yang dapat ditolerir }(5 \% \text { atau } \\
& 0,05)
\end{aligned}
$$

Rumus perhitungan pengambilan sampel digunakan pada total populasi 84 orang, didapatkan hasil perhitungan yakni 79,358. Apabila hasil digenapkan didapatkan besar sampel berjumlah 80 orang.

Penelitian ini dilaksanakan di PT. Bangun Sarana Baja Gresik yang berada di Jalan Mayjend Sungkono XII No. 8, Gresik, Jawa Timur. Waktu pengambilan data dilaksanakan pada April 2017 sampai dengan Mei 2017.

Data yang dikumpulkan pada penelitian ini ialah data primer serta data sekunder. Data primer yaitu data yang diperoleh langsung dari observasi perilaku tidak aman pekerja, wawancara kepada manajer HSE untuk data penunjang dan pengisian kuesioner oleh responden di lapangan. Data sekunder merupakan data yang diperoleh dari pihak perusahaan khususnya bagian keselamatan dan kesehatan kerja (Departemen HSE) PT. Bangun Sarana Baja Gresik, seperti dokumen perusahaan, peraturan dan kebijakan perusahaan, SOP pengoperasian OHC, pencatatan serta pelaporan lain yang mendukung penelitian ini.

Variabel penelitian yang digunakan yakni variabel terikat (dependent) dan variabel bebas (independent). Variabel terikat atau dependent yakni perilaku tidak aman yang diperoleh dari pengamatan langsung di lapangan. Variabel bebas atau independent yakni pengawasan, kebijakan, dan pelatihan, yang diperoleh dari pengisian kuesioner oleh responden.

Teknik analisis data dalam penelitian ini dilakukan dengan menggunakan tabulasi silang. Melihat hubungan antara variabel secara statistik dengan menggunakan uji korelasi kontingensi, karena skala data terkecil yang digunakan adalah nominal. Setelah data dianalisis, langkah selanjutnya adalah melakukan penarikan kesimpulan.

\section{HASIL}

\section{Gambaran Umum Tempat Penelitian}

PT. Bangun Sarana Baja yang berlokasi dan berkantor pusat di Jl. Mayjend Sungkono XII/8 Gresik pertama kali didirikan pada tahun 1985 dengan luas lahan hanya $16.000 \mathrm{~m}^{2}$. Seiring dengan berjalannya waktu maka untuk memenuhi pesanan dan mendukung perkembangan perusahaan semakin pesat sehingga area perusahaan diperluas menjadi total $130.000 \mathrm{~m}^{2}$. Selain itu dibangun pula cabang perusahaan yang berlokasi di Jakarta dan Surabaya.

Area workshop PT. Bangun Sarana Baja Gresik dilengkapi dengan berbagai jenis peralatan kerja yang mendukung dalam proses produksi. Peralatan kerja yang dimiliki oleh PT. Bangun Sarana Baja Gresik meliputi handtool dan peralatan berat. Penggunaan handtool untuk proses fitting, marking, cutting, drilling, assembling, welding, dan grinding. PT. Bangun Sarana Baja Gresik juga memiliki mesin dan peralatan berat yang juga mendukung dalam proses produksi, seperti mesin CNC yang merupakan mesin otomatis untuk proses punching dan cutting.

Peralatan berat lainnya yakni overhead crane (OHC) yang merupakan alat angkat-angkut yang digunakan dalam proses produksi dimana digunakan untuk mengangkat dan memindahkan material dari satu tempat ke tempat lain selama proses produksi. Alat angkat-angkut lainnya yang digunakan oleh PT. Bangun Sarana Baja Gresik adalah forklift yang digunakan untuk pengangkutan material.

\section{Distribusi Pekerja Berdasarkan Perilaku}

Tabel 3 menunjukkan bahwa dari total jumlah pekerja, sebanyak 64 pekerja ( $80 \%$ ) berperilaku tidak aman selama pengoperasian overhead crane. Sedangkan pekerja yang berperilaku aman berjumlah 16 orang $(20 \%)$. 
Tabel 3. Distribusi Frekuensi Pekerja di PT. Bangun Sarana Baja Gresik Berdasarkan Perilaku Tahun 2017

\begin{tabular}{llc}
\hline \multicolumn{1}{c}{ Perilaku } & N & \% \\
\hline Tidak Aman & 64 & 80 \\
Aman & 16 & 20 \\
\hline Total & 80 & 100 \\
\hline
\end{tabular}

Terdapat beberapa jenis perilaku tidak aman yang dilakukan pekerja dalam pengoperasian overhead crane. Pengelompokan jenis perilaku tidak aman yang diamati yakni berdasarkan pada teori domino, sehingga didapatkan distribusi pekerja berdasarkan jenis perilaku yang disajikan dalam Tabel 4.

Tabel 4 menunjukkan bahwa terdapat tiga jenis perilaku tidak aman yang paling banyak dilakukan oleh pekerja dalam pengoperasian overhead crane. Jenis perilaku tidak aman yang sering dilakukan adalah pekerja yang sebenarnya tidak memiliki kewenangan dalam mengoperasikan overhead crane (OHC), yakni pekerja yang tidak memiliki Surat Ijin Operasi (SIO), namun tetap mengoperasikan overhead crane (OHC) (78,1\%); pekerja tidak memakai sarung tangan saat mengoperasikan overhead crane (OHC) (64\%); dan pekerja yang tidak menggunakan alat bantu angkat dan angkut yang sesuai melainkan menggunakan catok (55\%).

\section{Distribusi Pekerja Berdasarkan Faktor Eksternal}

Tabel 5 menunjukkan bahwa pada variabel pengawasan dan kebijakan dikategorikan menjadi 2 yaitu cukup baik dan baik. Variabel pelatihan dikategorikan menjadi 2 yaitu "tidak", bagi pekerja yang tidak pernah mengikuti pelatihan dan "ya", bagi pekerja yang pernah mengikuti pelatihan.

Pada kolom pengawasan diketahui bahwa sebesar 50 pekerja $(62,5 \%)$ menganggap bahwa pengawasan yang ada di perusahaan dengan nilai cukup baik. Sedangkan jumlah pekerja yang telah menganggap baik pengawasan yang ada yakni 30 orang (37,5\%). Pada kolom kebijakan menunjukkan bahwa sebagian besar pekerja yakni 46 orang (57,5\%) menilai kebijakan perusahaan dengan kategori nilai baik. Sebesar 34 pekerja $(42,5 \%)$ menganggap bahwa kebijakan perusahaan cukup baik.
Tabel 4. Distribusi Frekuensi Pekerja Berdasarkan Jenis Perilaku Tidak Aman di PT. Bangun Sarana Baja Gresik Tahun 2017

\begin{tabular}{|c|c|c|}
\hline Jenis Perilaku Tidak Aman & $\mathbf{N}$ & $\%$ \\
\hline Bekerja tidak sesuai SOP & 2 & 3,1 \\
\hline $\begin{array}{l}\text { Tidak memakai sarung tangan (safety } \\
\text { gloves) }\end{array}$ & 41 & 64 \\
\hline $\begin{array}{l}\text { Tidak memakai pelindung kepala } \\
\text { (safety helmet) }\end{array}$ & 27 & 42,1 \\
\hline $\begin{array}{l}\text { Tidak memakai sepatu pelindung (safety } \\
\text { shoes) }\end{array}$ & 9 & 14 \\
\hline $\begin{array}{l}\text { Beban yang diangkat/dipindahkan } \\
\text { melebihi SWL }\end{array}$ & 0 & 0 \\
\hline $\begin{array}{l}\text { Pendant control tidak berfungsi dengan } \\
\text { baik }\end{array}$ & 8 & 13 \\
\hline $\begin{array}{l}\text { SWL tidak tertera dengan jelas pada } \\
\text { hook atau pada badan } \mathrm{OHC}\end{array}$ & 0 & 0 \\
\hline $\begin{array}{l}\text { Tidak menggunakan alat bantu } \\
\text { yang sesuai untuk mengangkat dan } \\
\text { mengangkut beban (contoh: tidak } \\
\text { menggunakan webbing sling dan hanya } \\
\text { memakai catok) }\end{array}$ & 35 & 55 \\
\hline $\begin{array}{l}\text { Webbing sling yang digunakan } \\
\text { berserabut dan robek }\end{array}$ & 11 & 17,1 \\
\hline $\begin{array}{l}\text { Tidak memastikan area atau lintasan } \\
\text { yang akan dilewati } \mathrm{OHC} \text { aman/steril } \\
\text { (terdapat benda/material/pekerja lain } \\
\text { yang menghalangi akses jalan) }\end{array}$ & 3 & 5 \\
\hline Memindahkan material dengan cepat & 0 & 0 \\
\hline $\begin{array}{l}\text { Tidak memastikan posisi material yang } \\
\text { akan diangkat dan diangkut mempunyai } \\
\text { posisi tegak lurus dengan hook (hook } \\
\text { berada pada titik imbang material) }\end{array}$ & 2 & 3,1 \\
\hline $\begin{array}{l}\text { Tidak memiliki kewenangan dalam } \\
\text { mengoperasikan OHC dengan tidak } \\
\text { memiliki Surat Izin Operasi (SIO) }\end{array}$ & 50 & 78,1 \\
\hline
\end{tabular}

Tabel 5. Distribusi Frekuensi Pekerja Berdasarkan Faktor Eksternal di PT. Bangun Sarana Baja Gresik Tahun 2017

\begin{tabular}{clcc}
\hline Variabel & \multicolumn{1}{c}{ Kategori } & $\mathbf{N}$ & $\mathbf{\%}$ \\
\hline \multirow{2}{*}{ Pengawasan } & Cukup baik & 50 & 62,5 \\
& Baik & 30 & 37,5 \\
\multirow{3}{*}{ Kebijakan } & Cukup baik & 34 & 42,5 \\
& Baik & 46 & 57,5 \\
& Tidak & 50 & 62,5 \\
& Ya & 30 & 37,5 \\
\hline
\end{tabular}


Hasil penelitian ini menunjukkan bahwa sebagian besar pekerja tidak pernah mengikuti pelatihan dengan jumlah 50 orang $(62,5 \%)$. Pekerja yang pernah mengikuti pelatihan sebesar 30 orang $(37,5 \%)$.

\section{PEMBAHASAN}

\section{Perilaku Tidak Aman}

Perilaku tidak aman merupakan tindakan tidak aman menurut Heinrich dalam teori Domino yang kemudian disesuaikan dengan lingkungan pekerja dalam pengoperasian overhead crane (OHC). Hasil observasi pada Tabel 3. menunjukkan bahwa sebagian besar responden yakni 64 pekerja $(80 \%)$ dari jumlah total 80 orang masih melakukan perilaku tidak aman saat pengoperasian overhead crane dibandingkan dengan jumlah pekerja yang berperilaku aman sebanyak 16 orang (20\%). Pada Tabel 4. diketahui bahwa tiga perilaku tidak aman yang paling banyak dilakukan oleh pekerja dalam pengoperasian overhead crane yaitu sebesar 50 pekerja $(78,1 \%)$ tidak memiliki kewenangan, yakni pekerja yang tidak memiliki Surat Izin Operasional (SIO) pengoperasian overhead crane, 41 pekerja (64\%) tidak menggunakan safety gloves atau sarung tangan, dan 35 pekerja (55\%) tidak menggunakan alat bantu yang sesuai saat mengoperasikan overhead crane.

Pengoperasian overhead crane di PT. Bangun Sarana Baja Gresik memperbolehkan siapa saja, yakni seluruh pekerja workshop, termasuk pekerja yang tidak memiliki SIO untuk mengoperasikan overhead crane. Hal ini disebabkan oleh karena tidak adanya pekerja yang ditugaskan khusus sebagai operator overhead crane sehingga pekerja workshop apapun dapat mengoperasikan overhead crane.

Tuntutan pekerjaan yang banyak tidak seimbang dengan kurangnya pekerja yang telah mengikuti pelatihan mengenai overhead crane dan sedikitnya pekerja yang memiliki SIO untuk mengoperasikan overhead crane menjadi salah satu penyebab pekerja yang tidak memiliki kewenangan diperbolehkan untuk mengoperasikan overhead crane di PT. Bangun Sarana Baja Gresik. Sehingga masih banyak pekerja yang meskipun tidak memiliki SIO tetap mengoperasikan $\mathrm{OHC} \mathrm{Hal}$ ini bertentangan dengan Permenakertrans RI No. 09 Tahun 2010 yang menyebutkan bahwa pesawat angkat dan angkut harus dioperasikan oleh operator pesawat angkat dan angkut yang telah memiliki lisensi K3 atau SIO.
Pemakaian safety gloves dalam pengoperasian overhead crane dapat melindungi pekerja dari sengatan arus listrik yang terdapat pada pendant control. Masih banyak ditemukan pekerja yang memegang pendant control dengan tangan kosong atau secara langsung. Secara tidak langsung dapat meningkatkan kemungkinan terjadinya kecelakaan kerja.

Terdapat berbagai cara dalam mengurangi kemungkinan kecelakaan kerja. Salah satunya dapat dilakukan dengan meningkatkan frekuensi penggunaan alat pelindung diri pada bagian produksi. Tingkat penggunaan alat pelindung diri sangat berpengaruh pada tingkat keselamatan kerja. Semakin rendah frekuensi penggunaan alat pelindung diri maka semakin besar kesempatan terjadinya kecelakaan kerja (Handayani, 2010).

Pengangkatan dan pengangkutan material dengan menggunakan OHC membutuhkan alat bantu tersendiri. Alat bantu yang dimaksud adalah alat bantu yang digunakan untuk mengangkat dan mengangkut material seperti webbing sling atau chain sling. Masih banyak pekerja yang menggunakan catok, yakni alat bantu angkat berbahan besi yang dibuat sendiri oleh pekerja, untuk mengangkat dan mengangkut material yang dapat memperbesar kemungkinan untuk terjadinya kecelakaan kerja. Pada Permenakertrans RI No. PER.09/MEN/VII/2010 menyatakan bahwa alat bantu pada pesawat angkat dan angkut harus dipilih sesuai dengan kapasitas beban kerja aman. Pada webbing sling dan chain sling tertera Safety Weight Load (SWL) atau batas beban yang diperbolehkan dalam pengangkatan sehingga pekerja dapat mengetahui batas aman dalam pengangkatan material. Berbeda dengan penggunaan catok, tidak tertera SWL pada catok sehingga pekerja tidak dapat mengetahui batas beban angkat yang diperbolehkan. Ramli (2010) menyebutkan bahwa tindakan yang tidak aman oleh manusia di tempat kerja saat melakukan pekerjaan merupakan salah satu penyebab terjadinya kecelakaan kerja.

\section{Pengawasan}

Pengawasan merupakan penilaian pekerja mengenai pelaksanaan pengawasan yang ada di perusahaan. Kategori penilaian dibagi menjadi dua yakni cukup baik dan baik. Sebagian besar pekerja, yakni 50 pekerja $(62,5 \%)$, menyatakan bahwa pengawasan yang dilakukan oleh perusahaan tergolong cukup baik. Pengawasan yang ada 
dilakukan oleh HSE inspector atau HSE officer dari Departemen HSE PT. Bangun Sarana Baja Gresik, dimana setiap hari HSE officer dan/atau HSE inspector berkeliling untuk mengawasi lingkungan kerja dan tingkah laku pekerja selama pekerja termasuk tindakan tidak aman dalam bekerja yang dilakukan oleh pekerja.

Adanya pengawasan diperlukan untuk mengubah perilaku pekerja. Pelaksanaan pengawasan yang rutin akan mendorong motivasi pekerja untuk berperilaku aman. Pengawasan dapat mengingatkan pekerja untuk selalu bekerja dengan baik dan benar serta berperilaku aman. Sebaliknya, apabila pelaksanaan pengawasan tidak dilakukan secara rutin maka pekerja akan merasa bebas dalam melakukan pekerjaan dan menjadi tidak tahu apakah pekerjaannya telah dilakukan secara benar dan aman atau tidak sehingga pekerja cenderung akan berperilaku tidak aman (Saragih dkk, 2014).

\section{Kebijakan}

Kebijakan adalah tanggapan pekerja mengenai kebijakan K3 perusahaan yang diterapkan pada kalangan pekerja dalam perusahaan. Penilaian dibagi menjadi dua kategori yaitu cukup baik dan baik. Hasil penelitian menunjukkan bahwa lebih dari setengah responden yakni sebanyak 46 pekerja (57,5\%) memiliki tanggapan yang tergolong baik terhadap kebijakan K3 perusahaan. Sebagian besar pekerja menganggap bahwa peraturan dan kebijakan telah dijalankan secara konsisten dan merasa bahwa PT. Bangun Sarana Baja Gresik memiliki peraturan dan kebijakan K3 dalam operasional perusahaan, dimana peraturan dan kebijakan dilaksanakan dan ditujukan untuk mengarahkan dan melindungi pekerja dalam bekerja.

Halimah (2010) menyatakan bahwa kebijakan yang dilakukan secara menyeluruh secara tidak langsung dapat membentuk perilaku pekerja dalam bekerja. Kebijakan dibuat agar pekerja terhindar dari perilaku tidak aman dan dapat berperilaku aman. Kebijakan yang merupakan sebuah peraturan dalam bentuk tulisan yang memerlukan pengawasan yang teratur dan konsisten dalam pelaksanaannya agar kepatuhan terhadap kebijakan semakin meningkat sehingga angka pekerja yang melakukan perilaku tidak aman akan semakin rendah.

\section{Pelatihan}

Pelatihan merupakan kondisi keikutsertaan pekerja dalam pelatihan. Pelatihan dibedakan menjadi dua kategori yaitu kategori "ya" untuk pekerja yang pernah mengikuti pelatihan dan "tidak" untuk pekerja yang tidak pernah mengikuti pelatihan. Pelatihan yang dimaksud adalah pelatihan mengenai overhead crane yang dilaksanakan baik di dalam ataupun di luar perusahaan. Sebagian besar pekerja yakni sebanyak 50 orang $(62,5 \%)$ menyatakan tidak pernah mengikuti pelatihan pengoperasian overhead crane baik pelatihan yang diadakan oleh perusahaan atau pelatihan di luar perusahaan.

Terdapat dua jenis pelatihan overhead crane pada PT. Bangun Sarana Baja Gresik yakni pelatihan internal dan eksternal. Pelatihan internal diadakan oleh PT. Bangun Sarana Baja Gresik dengan Departemen HSE sebagai pemateri. Pelatihan ini disebut dengan refresh training. Pelatihan eksternal yakni pelatihan yang bekerja sama dengan PJK3 dan Dinas Ketenagakerjaan dalam pemberian materi. Pelatihan ini yang selanjutnya akan menghasilkan lisensi K3 atau SIO bagi pekerja yang menjadi peserta.

Delfianda (2012) berpendapat bahwa pelatihan umum dilakukan untuk membiasakan pekerja agar pekerja dapat bekerja secara aman dan selamat. Pelatihan ditujukan untuk mempersiapkan pekerja dalam menghadapi risiko bahaya dan mengetahui langkah-langkah pencegahan dan penanggulangan bahaya tersebut. Pelatihan merupakan salah satu upaya untuk meningkatkan kompetensi pekerja dalam melakukan pekerjaan sesuai standar K3 yang diterapkan di tempat kerja dan sebagai salah satu upaya dalam menjauhkan pekerja dari perilaku tidak aman dalam bekerja. Pelatihan sebaiknya diberikan kepada pekerja secara rutin guna membiasakan pekerja dalam pekerjaannya.

\section{Hubungan Faktor Eksternal dengan Perilaku Tidak Aman}

Tabel 6 menunjukkan bahwa variabel pada faktor eksternal mendominasi dalam hubungan dengan perilaku tidak aman. Nilai sig. $<0,05$ menunjukkan bahwa variabel memiliki hubungan dengan variabel yang lain. Uji statistik yang dilakukan menunjukkan pengawasan dengan nilai sig. 0,004 dan pelatihan dengan nilai sig. 0,000 menunjukkan bahwa pengawasan dan pelatihan berhubungan dengan perilaku tidak aman. Sebaliknya dengan kebijakan yang memiliki nilai sig. 0,113 lebih besar dari 0,05 menunjukkan tidak ada hubungan antara kebijakan dengan perilaku tidak aman. 
Tabel 6. Distribusi Hubungan Faktor Eksternal dengan Perilaku Tidak Aman Pekerja di PT. Bangun Sarana Baja Gresik Tahun 2017

\begin{tabular}{lcc}
\hline Variabel & Sig. & Hubungan \\
\hline Pengawasan & 0,004 & Ada hubungan \\
Kebijakan & 0,113 & Tidak ada hubungan \\
Pelatihan & 0,000 & Ada hubungan \\
\hline
\end{tabular}

\section{Hubungan Pengawasan dengan Perilaku tidak Aman}

Stranks (2003) menyatakan bahwa pengawasan merupakan kunci untuk memastikan tempat kerja dalam kondisi aman. Pengawasan yang dilakukan dengan tujuan memotivasi pekerja untuk bekerja dengan baik dan benar dan memastikan setiap pekerja tahu apa yang dikerjakannya akan memberikan kondisi dan lingkungan kerja yang aman serta dapat menghasilkan perilaku aman pekerja. Pengawas berperan penting dalam memberikan pengaruh pengetahuan, sikap dan perilaku aman kepada pekerja terhadap tanggung jawab pekerjaannya (Dewi, 2015). Oleh sebab itu, sudah sepantasnya jika hasil penelitian menunjukkan adanya hubungan antara pengawasan dengan perilaku tidak aman, jumlah pekerja yang berperilaku tidak aman dengan penilaian yang lebih rendah, yakni cukup baik, terhadap pengawasan lebih banyak dibandingkan dengan pekerja yang berperilaku tidak aman yang memiliki penilaian baik terhadap pengawasan.

Uji Statistik menunjukkan hasil nilai sig. yakni $0,004<\alpha(0,05)$ yang berarti terdapat hubungan antara pengawasan dengan perilaku tidak aman. Penelitian yang dilakukan oleh Listyandini (2013) juga menyatakan hal yang serupa bahwa ada hubungan antara pengawasan dengan perilaku tidak aman. Dapat disimpulkan bahwa pengawasan yang dilakukan setiap hari oleh Departemen HSE dapat mencegah pekerja untuk berperilaku tidak aman.

\section{Hubungan Kebijakan dengan Perilaku tidak Aman}

Notoatmodjo (2003) menyatakan bahwa salah satu strategi perubahan perilaku adalah dengan menggunakan kekuasaan dan kekuatan salah satunya dengan kebijakan yang menuntut untuk dipatuhi oleh pekerja. Oleh sebab itu, kebijakan yang baik akan cenderung membuat pekerja mematuhinya dan berperilaku aman dalam bekerja. Hasil penelitian bertolak belakang dengan teori tersebut dengan hasil tidak adanya hubungan antara kebijakan dengan perilaku tidak aman. Hasil yang sama juga terdapat pada penelitian yang dilakukan oleh Kurniawati (2014), tidak ada hubungan antara peraturan dengan perilaku tidak aman.

Kepatuhan terhadap kebijakan yang ada menjadi salah satu penyebab masih banyaknya pekerja yang melakukan perilaku tidak aman meskipun pandangan terhadap kebijakan yang ada dinilai baik. Salah satu contoh ketidakpatuhan akan kebijakan dapat dilihat berdasarkan hasil observasi, masih banyak pekerja yang tidak memakai APD saat bekerja dimana tidak memakai APD sendiri adalah salah satu bentuk dari perilaku tidak aman. Kebijakan K3 di tempat kerja juga telah disosialisasikan bahwa pekerja wajib menggunakan APD saat bekerja dalam area wajib APD. Halimah (2010) menjelaskan bahwa kepatuhan merupakan ketaatan melakukan sesuatu yang telah ditetapkan atau dianjurkan, seperti mematuhi atau menjalani peraturan yang berlaku. Semakin banyak pekerja yang menerapkan peraturan perusahaan maka dapat dikatakan patuh, namun apabila sebaliknya maka dianggap tidak patuh.

\section{Hubungan Pelatihan dengan Perilaku tidak Aman}

Kurniawati (2014) menjelaskan bahwa pelatihan yang merupakan proses belajar yang akan memperoleh pengalaman belajar nantinya akan menimbulkan perubahan perilaku bagi pekerja yang mengikuti pelatihan sebagai hasilnya. Pelatihan bertujuan untuk meningkatkan keterampilan dan pengetahuan seseorang akan sesuatu hal. Pekerja yang mengikuti pelatihan akan memperoleh pengetahuan dan keterampilan dalam bekerja sehingga dapat menyelesaikan pekerjaannya dengan aman, efisien, dan efektif. Pekerja yang mengikuti pelatihan maka akan meningkatkan kompetensi pekerja dalam melakukan pekerjaannya.

Masih banyaknya pekerja yang belum pernah mengikuti pelatihan, salah satunya disebabkan oleh tidak adanya pelaksanaan pelatihan yang diadakan oleh perusahaan. Wawancara yang dilakukan dengan manajer HSE menunjukkan bahwa PT. Bangun Sarana Baja Gresik belum mengadakan dan memberikan pelatihan pengoperasian overhead crane dengan jadwal yang rutin akibat dari terkendala biaya. Pelatihan jika telah dilaksanakan sesuai dengan jadwal seharusnya, maka pekerja akan cenderung berperilaku aman dalam bekerja. 
Kurniawati (2014) menyatakan bahwa dengan diadakannya pelatihan, maka perusahaan akan mendapatkan keuntungan dengan rendahnya kejadian kecelakaan kerja. Hal ini mengingat bahwa dengan mengikuti pelatihan maka pekerja akan memperoleh pengetahuan mengenai pekerjaannya yang mencakup bahaya dan penanganannya. Pekerja dapat menghindari perilaku tidak aman dan akan cenderung melakukan pekerjaan dengan aman.

Hasil uji statistik didapatkan nilai sig. $<\alpha(0,05)$ dengan jumlah 0,000 yang berarti terdapat hubungan antara pengetahuan dengan perilaku tidak aman. Penelitian yang dilakukan oleh Abiszah (2014) juga menyatakan bahwa ada hubungan antara pelatihan dengan perilaku tidak aman. Pelatihan kerja diselenggarakan guna membekali, meningkatkan, dan mengembangkan kompetensi kerja untuk meningkatkan kemampuan kerja seseorang. Pekerja dengan pengetahuan yang baik maka dapat berpikir dan memutuskan pilihan yang baik pada pekerjaannya. Pengetahuan kerap dikaitkan dengan pembentukan perilaku atau tindakan pekerja dalam bekerja.

\section{SIMPULAN}

Penelitian ini dilakukan kepada pekerja yang mengoperasikan overhead crane di PT. Bangun Sarana Baja Gresik. Kesimpulan dari penelitian ini ialah sebagian besar pekerja menilai cukup baik terhadap pengawasan yang dilakukan oleh perusahaan. Di samping itu, sebagian besar pekerja menganggap bahwa penerapan kebijakan K3 di perusahaan telah baik. Sebagian besar pekerja belum pernah mengikuti pelatihan mengenai overhead crane baik di dalam perusahaan ataupun di luar perusahaan.

Hasil observasi terhadap perilaku tidak aman pekerja menunjukkan bahwa sebagian besar pekerja memiliki perilaku tidak aman saat mengoperasikan overhead crane. Perilaku tidak aman yang paling banyak dilakukan oleh pekerja adalah bekerja tanpa wewenang, tidak menggunakan safety gloves, dan memakai alat bantu selain alat bantu yang telah ditentukan untuk mengangkat dan mengangkut material.

Uji statistik yang telah dilakukan menunjukkan bahwa variabel pada faktor eksternal mendominasi dalam memiliki hubungan dengan perilaku tidak aman, yakni dua variabel dari tiga variabel. Variabel yang memiliki hubungan yaitu pengawasan dan pelatihan.

\section{DAFTAR PUSTAKA}

Abiszah., 2014. Faktor yang Berhubungan dengan Tindakan tidak Aman Pekerja Job PertaminaPetrochina East Java. Skripsi. Surabaya: Fakultas Kesehatan Masyarakat Universitas Airlangga.

Basuki., 2012. Analisis Intervensi Penyuluhan Penyakit Jantung Koroner terhadap Perubahan Tingkat Pengetahuan dan Sikap Pegawai Universitas Terbuka yang Berpotensi Penyakit Jantung Koroner Tahun 2011. Tesis. Jakarta: Fakultas Kesehatan Masyarakat Universitas Indonesia.

Bikatofani, R.R., 2015. Analisis Risiko Pengoperasian Overhead Crane Double Girder di Divisi Kapal Niaga PT. PAL Surabaya. The Indonesian Journal of Occupational Safety and Health. [e-journal] Vol. 4. No. 1.

Bureau of Labor Statistics., 2008. Crane-Related Occupational Fatalities. [online]. Tersedia di: http://bls.gov. [diakses tanggal 15 Desember 2016]

Cooper, D., 2009. Behavioral and Safety Framework for Success. Indiana: BSMS Inc.

Delfianda., 2012. Survey Faktor Tindakan tidak Aman Pekerja Konstruksi PT. Waskita Karya Proyek World Class University di UI Depok Tahun 2011. Skripsi. Depok: Fakultas Kesehatan Masyarakat Universitas Indonesia.

Dewi, N., 2015. Analisis Faktor yang Berhubungan dengan Tindakan tidak Aman (Unsafe Action) pada Pekerja Bagian Plastik PT. X. Skripsi. Surabaya: Fakultas Kesehatan Masyarakat Universitas Airlangga.

Halimah, S., 2010. Faktor-Faktor yang Mempengaruhi Perilaku Aman Karyawan di PT. SIM PLANT TAMBUN II Tahun 2010. Skripsi. Jakarta: Fakultas Kedokteran dan Ilmu Kesehatan Universitas Islam Negeri Syarif Hidayatullah Jakarta.

Handayani, E., 2010. Hubungan Antara Penggunaan Alat Pelindung Diri, Umur dan Masa Kerja dengan Kecelakaan Kerja pada pekerja Bagian Rustic di PT. Borneo Melintang Buana Eksport Yogyakarta. Jurnal Kesehatan Masyarakat. [e-journal] Vol. 4. No. 3.

Kementerian Perindustrian., 2012. Perencanaan Kebutuhan energi Sektor Industri dalam 
Rangka Akselerasi Industrialisasi. Jakarta: Biro Perencanaan Sekretariat Jenderal Kementerian Perindustrian.

Kurniawati, G., 2014. Analisis Faktor yang Berhubungan dengan Perilaku tidak Aman pada Pekerja di Bagian Assembly PT. PAL Indonesia. Skripsi. Surabaya: Fakultas Kesehatan Masyarakat Universita Airlangga.

Listyandini, R., 2013. Analisis Faktor yang Berhubungan dengan Perilaku tidak Aman pada Pekerja Kontraktor di PT. X. Skripsi. Surabaya: Fakultas Kesehatan Masyarakat Universitas Airlangga.

Notoatmodjo, S., 2003. Pendidikan dan Perilaku Kesehatan. Jakarta: PT. Rineka Citra.

Peraturan Menteri Tenaga Kerja dan Transmigrasi RI Nomor 05 Tahun 1985. Tentang Pesawat Angkat dan Angkut. Jakarta: Kementerian Ketenagakerjaan dan Transmigrasi.

Peraturan Menteri Tenaga Kerja RI Nomor 09 Tahun 2010. Tentang Operator dan Petugas Pesawat Angkat dan Angkut. Jakarta: Kementerian Ketenagakerjaan.
Ramli, S., 2010. Sistem Manajemen Kesehatan dan Keselamatan Kerja: OHSAS 18001. Cetakan kedua. Jakarta: Dian Rakyat.

Riduwan., 2013. Metode dan Teknik Menyusun Tesis. Bandung: Alfabeta.

Saragih, F., Lubis, H., Tarigan, L., 2014. FaktorFaktor yang Berhubungan dengan Tindakan Tidak Aman pada Pekerja Lapangan PT. Telkom Cabang Sidikalang Kabupaten Dairi Tahun 2014. Jurnal Kesehatan Masyarakat. [e-journal].

Stranks, J., 2003. The Handbook of Health and Safety Practices. New Jarsey: Pearson Education.

The Center For Construction Research and Training., 2016. Crane-Related Deaths in Construction and Recommendations for Their Prevention. [online] Tersedia di: <www.nccco.org/docs/ default-source/crane-safety-studies/crane-relateddeaths-in-construction-and-recommendationsfor-their-prevention.pdf.> [diakses tanggal 15 Desember 2016]. 